\title{
Microbial Diversity and their Role in Agaricus bisporus Production
}

\author{
Kanika Mahajan", Sunil Kumar ${ }^{1 *}$, Anil Rao ${ }^{2}$ and Ambrish Kumar Mahajan ${ }^{1}$ \\ ${ }^{1}$ Central University of Himachal Pradesh, Kangra-176206, H.P., India \\ ${ }^{2}$ ICAR-Directorate of Mushroom Research-DMR Solan, Himachal Pradesh, India \\ *Corresponding author
}

\begin{tabular}{l} 
K e y w o r d s \\
Agaricus bisporus, \\
Compost, Casing, \\
Microbial ecology, \\
Bacteria, Fungi \\
\hline Article Info \\
\hline $\begin{array}{l}\text { Accepted: } \\
\text { 15 June } 2021 \\
\text { Available Online: } \\
\text { 10 July } 2021\end{array}$ \\
\hline
\end{tabular}

\section{A B S T R A C T}

Mushrooms are a significant food crop for large population throughout the globe. The main edible mushroom is the button mushroom (Agaricus bisporus), a perfect example of economical food production which is manufactured on a specific manure delivered from farming residue materials. In mushroom cultivation successive microbial community consists of a variety of microorganisms including bacteria, actinomycetes and fungi at first breakdown the straw to form lignin humus complex and discharge the gases, and then metabolise the cellulose and hemicellulose into compost microbial biomass. This decayed straw along with microbial biomass turns into an organic and inorganic nutrient source for the mushroom mycelium and these micoflora play a main role during the different stages of composting and resist the growth of other competitor in the crop production. In most farms, seasonal cultivation of this mushroom is being practiced, but they are vulnerable to a spread of viral, bacterial and fungal diseases. Standardization of compost composition and composting processes, disinfection of casing soil, cultural practices, and sanitation has significantly reduced the prevalence of those moulds in mushroom crops.

\section{Introduction}

China, Malaysia, India, and Ireland are driving in worldwide mushroom production (Hanafi et al., 2018). China is the world's biggest grower of eatable mushrooms, providing more than 30 million $\mathrm{t}$, or $87 \%$ of worldwide contribution (Royse and Beelman 2016). Multiple thousands mushroom species exist in nature, however just around 22 species are cultivated
(Raj and Thangaraj 2008). Agaricus bisporus is a heterotrophicst edible basidiomycete which is the most famous consumable mushroom on the planet (Atila 2017). Mushrooms are devoured for their deliciousness, they are very rich in proteins with a significant substance of fundamental amino-acids and because of low starch and cholesterol, they suit diabetic and heart patients (Gupta et al., 2019; Sharma et al., 
2017). The initial step of mushroom cultivation is the compost production and it is a complex microbial process in which microorganisms decompose and stabilize the organic substrates under controlled conditions (Johri and Rajni 1999) and many factors involved in the composting process like microbial succession, raw material used for compost preparation, $\mathrm{pH}$, temperature, aeration and acidity or alkalinity (Antunes et al., 2016).

\section{Compost bacterial and fungal community}

Microbial ecosystem of the compost changes drastically during different stages of fermentation in the mushroom crop production, bacterial community increases with every step of mushroom cultivation compare to fungal community in mushroom cropping process (Vieira and Pecchia, 2018); (Siyoum et al., 2016); (McGee et al., 2017). Phase I in mushroom crop production is a thermobiological process which involves the bioconversion of simple carbohydrates and proteins by mesophillic microorganisms such as acinetobacter sphingomonas, Solibacillus, pseudomonas and comamonas known as pioneer community (Kertesz and Thai 2018).

Mesophilic microorganisms present in Phase I digest easily degradable polysachride, which raise the temprature and cause the shifting of mesophilic microorganisms to thermophilic microbial community (Smith et al., 1995). In phase I the dominant bacterial phylum are Firmicutes, Proteobacteria, Actinobacteria, Bacteroidetes and Thermi. During Phase II heat treatment is given to the compost which stimulates the growth of thermophilic microbial community and protects the crop from its parasites (Mouthier et al., 2017); (Vieira and Pecchia 2018). Firmicutes and Proteobacteria phyla are the hydrogen producers from the wheat straw compost (Valdez et al., 2017) whereas Actinobacteria plays a main role in compost production responsible for cellulose decomposition, they are consistently exist and shows maximum growth in the later phase of composting (Wang et al., 2011) ;(Zhang et al.,2014). In phase III during spawn run there is decrease in Actinobacteria and Firmicutes and increase in Proteobacteria (Kertesz et al., 2016); (Carrasco et al., 2019).

Fungi involve a significant role in biological biomass pretreatment because of their strong ligninolytic action (Stajić et al., 2016). Thermophilic fungi promote the growth of A.bisporus by removing waste from compost and assimilate the free ammonia produced in Phase I and help to stimulate the growth of Agaricus mycelium (Ross and Harris 1983); (Straatsma et al., 1994).

\section{Microbial ecology of casing layer}

Casing is the top covering placed on the substrate, colonized by the host mycelium and it helps to stimulate the fructification in the crop. Quality, yield, and uniformity of the mushroom crop production depend upon the casing layer (Noble and Gaze 1996).

Bacterial population present in casing influence the A.bisporus production by releasing growth stimulating substances (Hume and Hayes 1972).

Most of bacterial species present in casing is mainly related to Psedomonas, Pedobacter and Caulobacter, act as growth promoting strains, promote mycelia growth or fruiting body formation (Schisler 1982). A.bisporus produces 1-Octen -3-ol and ethylene which has inhibitory role in the process of fructification and some bacteria has the property to lower the level of this compound which promote the growth of mycelium (Zhang et al., 2016); (Kües et al., 2018); (Fermor et al., 1991). 
Role of bacteria and fungi as disease causal agents

The white button mushroom is vulnerable to numerous diseases that unfavourably influence the crop productivity. There are different types of Trichoderma strains which are responsible for the serious diseases in the mushroom crop like green mould (Seaby 1996). Cobweb disease of white button mushroom caused by the Cladobotryum dendroides responsible for the major loss in the crop (Grogan 2008). Bacterial pathogens involved in mushroom diseases mostly present in casing material and cause the Bacterial blotch in the crop. Pseudomonas tolaasii causes Agaricus brown blotch and develop light yellow injuries which result in tissue damage and Pseudomonas gingeri causes Agaricus ginger blotch (Wells et al., 1996). A.bisporus is seriously affected by a disease, for example, Mycogone perniciosa, the causal agent of Wet Bubble Disease, Wet Bubble Disease causes economic loss in button mushroom overall (Sharma and Kumar 2000).

\section{Beneficial role of bacteria and fungi in mushroom crop production}

Mushroom growth promoting bacteria (MGPB) are potential agent to increase the growth of mushroom, MGP microbes promote the mycorrhizal growths, shortening the soil composting procedure, improving nature of the substrate by secretion of secondary metabolites and help in mushroom fructification (Pratiksha et al., 2017). A. bisporus produces 1-aminocyclopropane-1carboxylic corrosive (ACC) act as self inhibitory compound degenerate by the 1aminocyclopropane-1-carboxylic corrosive (ACC) deaminase producing bacteria present in the casing layer and reduce the ethylene level which obstruct the fructification (Chen $e t$ al., 2013). Pseudomonas, Azotobacter, Bacillus, Paenibacillus, Bradyrhizobium has a essential and stimulatory role for the growth of mushroom while indicating threat against competitive molds, have been accounted as biofertilizers (Zarenejad et al., 2012); (Jadhav et al., 2014); (Pratiksha et al., 2017). Mycothermus thermophilus (Scytalidium thermophilum) the thermophilic fungus, has been depicted as significant for development, improvement and yield of A. bisporus (Natvig et al., 2015). Disease management with the help of biological methods is the best alternate over the other methods, Bacillus velezensis QST 713 and Bacillus amyloliquefeciens MBI 600 are use to control the green mould disease and affect the growth of $T$. aggressivum (Milijaševi et al., 2015); (Pandin et al., 2018).

Mushroom cropping comprises of a number of events and microbial population dynamics varies from compost, casing to fruit body formation and it present in large amount in mushroom compost compared to casing and fresh mushroom samples.

There are many significant factors that impact the different varieties of microorganisms in the substrate such as type of cultivation, substrate material, fermentation time and type of wheat straw material. The dominating bacterial community present in the mushroom compost are members of the phyla Actinobacteria, Bacteriodetes, Firmicutes and Proteobacteria and except the basidiomycetous fungi A. bisporus, most fungal species found within the mushroom growing medium tend to belong to the phylum Ascomycotina.

Pseudomonadales contain the genra Pseudomonas are the dominant bacterial population in compost and casing layer is associate with the promotion of mushroom frutification and metabolise the volatile compounds which act as inhibitory component in the A.bisporus primordial formation and acts as bioinoculant and Mushroom Growth Promoting Bacterial (MGPB) to increase the yield in mushroom crop production. 
Table.1 Diversity of bacterial communities in compost and casing material

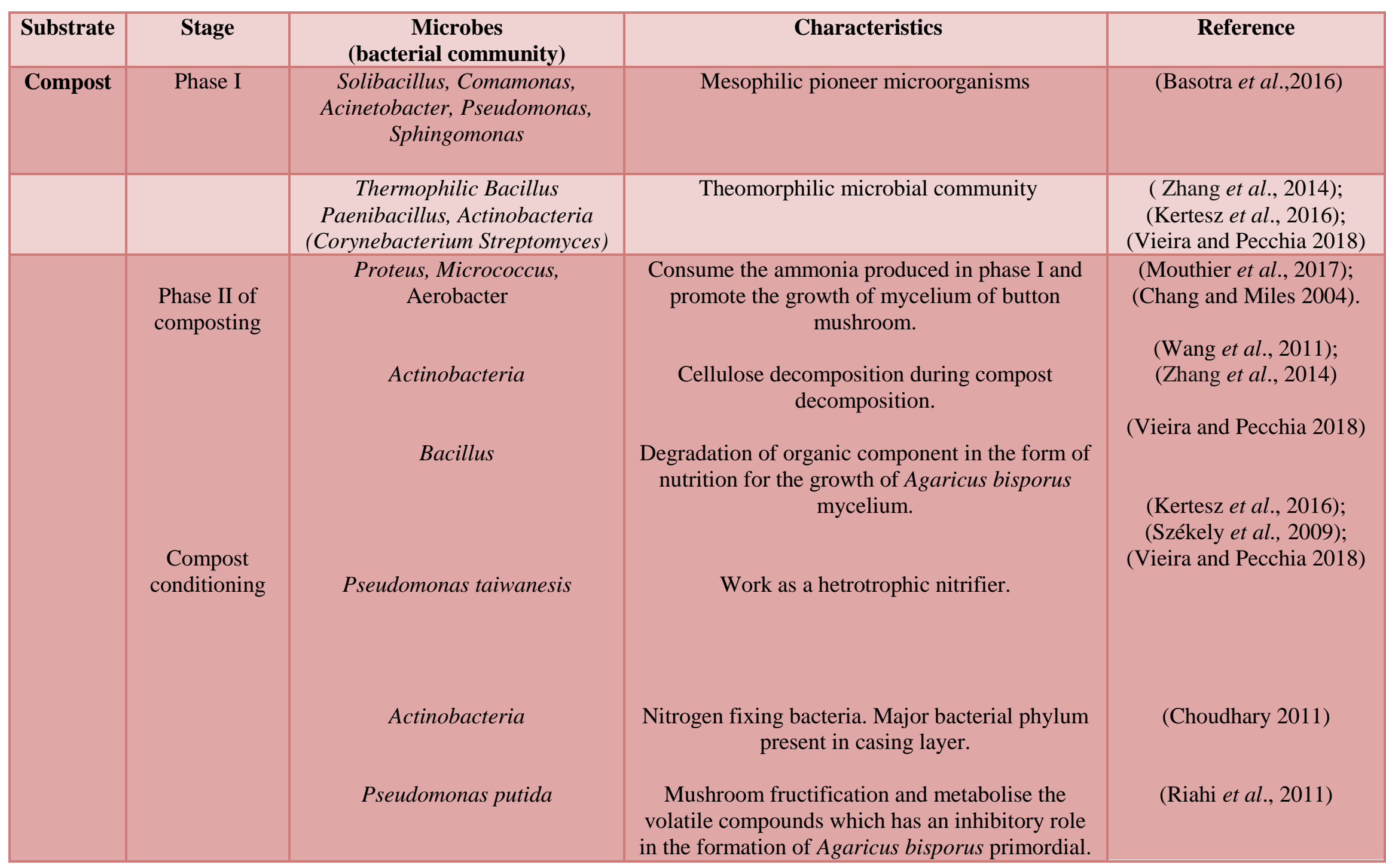


Table.2 Diversity of fungal communities in compost and casing material

\begin{tabular}{|c|c|c|c|c|}
\hline Substrate & Stage & Microbes(fungal community) & Characteristics & Reference \\
\hline \multirow[t]{4}{*}{ Compost } & Phase I & Lewia, Rhizomucor, Aspergillus & Mesophilic fungi & $\begin{array}{l}\text { (Kertesz et al., } \\
\text { 2016) }\end{array}$ \\
\hline & & $\begin{array}{c}\text { Aspergillus spp., Rhizopus oryzae, } \\
\text { Trichoderma viride, Chaetomium } \\
\text { spp., Penicillium spp., } \\
\text { Alternaria spp, } \\
\text { Talaromyces, thermomyces }\end{array}$ & $\begin{array}{l}\text { Dominant mycoflora in the initial phases of } \\
\text { composting, thermophilic fungi has positive } \\
\text { influence for the growth of A.bisporus by } \\
\text { decreasing the ammonia concentration and it } \\
\text { immobilize the nutrients so that it is easily } \\
\text { available to the mycelium of mushroom. }\end{array}$ & $\begin{array}{l}\text { (McGee } \text { et al., } \\
\text { 2017) }\end{array}$ \\
\hline & $\begin{array}{l}\text { Conditioning } \\
\text { process }\end{array}$ & $\begin{array}{c}\text { Thermophilic fungus Scytalidium } \\
\text { thermophilum }\end{array}$ & $\begin{array}{l}\text { Dominating cellulytic ascomycete, help in } \\
\text { degradation of polymeric carbohydrates }\end{array}$ & $\begin{array}{l}\text { (Vajna et al., } \\
\text { 2012); } \\
\text { (Kertesz et al., } \\
\text { 2016); } \\
\text { (Basotra et al., } \\
\text { 2016) }\end{array}$ \\
\hline & $\begin{array}{l}\text { Phase II of } \\
\text { composting }\end{array}$ & $\begin{array}{l}\text { Thermomyces ibadanensis, } \\
\text { Thermomyces lanuginosus and } \\
\text { Scytalidium thermophilum }\end{array}$ & Most abundant thermophilic fungal species & $\begin{array}{l}\text { (Zhang et al., } \\
\text { 2014) }\end{array}$ \\
\hline Casing & & $\begin{array}{l}\text { Paecilomyces niveus, Thermomyces } \\
\text { lanuginosus, Aspergillus spp., } \\
\text { Myceliophthora spp., Sordaria spp., } \\
\text { Candida subhashii, Lecanicillium } \\
\text { fungicola, and Cercophora spp. }\end{array}$ & Dominant fungal community in casing & $\begin{array}{l}\text { (Kertesz et al., } \\
\text { 2016) }\end{array}$ \\
\hline
\end{tabular}


Thermophilic fungi have positive influence for the growth of A.bisporus by decreasing the ammonia concentration and it immobilizes the nutrients so that it is easily available to the mycelium of mushroom.

The main constraints with the good productivity of this crop are microbial diseases, caused by different types of pathogens that result the partial or total failure of the crop. Disease control with the help of chemical fungicides stimulates the production of harmful component which effect the environment adversely however, evolution of resistance to fungicides and host sensitivity to fungicides are serious issues.

Throughout this review, it's emphasize that understanding the structure, dynamics and usefulness of the mushroom microbiota present in at different stages of crop cycle provides a foundation to change and improve current cultivation ways. More detailed and advanced studies are needed to explore the biocontrol agents and to develop consortia of bacteria and fungi that may be utilized in bioaugmentation and may be a potential tool and a chance to modify the mushroom crop production.

\section{Acknowledgements}

The authors are thankful to the Central University of Himachal Pradesh for providing the necessary infrastructural facilities for this review.

\section{References}

Antunes, L P, Martins L F, Pereira R V, Thomas A M, Barbosa D, Lemos L N (2016) Microbial community structure and dynamics in thermophilic composting viewed through metagenomics and metatranscriptomics. Sci Rep 6: 38915. DOI:

\section{$10.1038 /$ srep38915}

Atila F (2017) Evaluation of suitability of various agro-wastes for productivity of Pleurotus djamor, Pleurotus citrinopileatus and Pleurotus eryngii mushrooms. J Exp Agric Int 17(5):111.

https://doi.org/10.9734/JEAI/2017/363 46

Basotra N, Kaur B, Di Falco M, Tsang A, Chadha B S (2016) Mycothermus thermophilus (Syn. Scytalidium thermophilum): repertoire of a diverse array of efficient cellulases and hemicellulases in the secretome revealed". Bioresour Technol 222:413-421.

https://doi.org/10.1016/j.biortech.2016. 10.018

Carrasco J, Tello M L, de Toro M, Tkacz A, Poole P, Pérez-Clavijo M, Preston G (2019) Casing microbiome dynamics during button mushroom cultivation: implications for dry and wet bubble diseases. Microbiology 165: 611-624. https://doi.org/10.1099/mic.0.000792

Chen S, Qiu C, Huang T, Zhou W, Qi Y, Gao Y, et al., (2013) Effect of 1aminocyclopropane-1-carboxylic acid deaminase producing bacteria on the hyphal growth and primordium initiation of Agaricus bisporus. Fungal Ecol 6: 110-118. https://doi.org/10.1016/j.funeco.2012.0 8.003

Fermor T R, Wood D A, Lincoln S P, Fenlon J S (1991) Bacteriolysis by Agaricus bisporus. J Gen Microbiol 137: 15-22. https://doi.org/10.1099/00221287-137$1-15$

Finally induced diseases of Agaricus bisporus: biochemical mechanisms and impact on commercial mushroom production. Appl Microbiol Biotechnol 2010;86:63-73

Grogan H M (2008) Challenges facing 
mushroom disease control in the 21st century. In Lelley, J. I., Buswell, J. A. (Eds.), Proceeding of the Sixth International Conference on Mushroom Biology and Mushroom Products 120- 127. Bonn, Germany: WSMBMP.

Gupta S, Summuna B, Gupta M, Annepu S (2019) Edible Mushrooms: Cultivation, Bioactive Molecules, and Health Benefits. Bioactive Molecules in Food, Reference Series in Phytochemistry, Springer Nature Switzerland AG. https://doi.org/10.1007/978-3-31954528-8_86-1

Hanafi F, Rezania S, Taib S M, Din M F M, Yamauchi, M, Sakamoto M, Hara H, Park J, Ebrahimi S (2018) Environmentally sustainable applications of agro-based spent mushroom substrate (SMS): An overview. J. Mater. Cycles. Waste 20 (3): $\quad 1383 \quad-1396$. https://doi.org/10.1007/s10163-0180739-0

Hume D P and Hayes W A (1972) The production of fruit-body primordia in Agaricus bisporus (Lange) Sing on agarmedia. Mushr. Sci. 8: 527-532.

Jadhav A C, Shinde D B, Nadre S B, Deore D S (2014) Quality improvement of casing material and yield in milky mushroom (Calocybe indica) by using biofertilizers and different substrates. In: Proceedings of 8th international conference on mushroom biology and mushroom products (ICMBMP8). ICAR-Directorate of Mushroom Research, Solan, India. 359-364.

Johri B N, Rajni (1999) Mushroom compost: microbiology and application". In: Bagyaraj D J, Verma A, Khanna K K (eds) Modern approaches and innovation in soil management. Rastogi, Meerut, 345-358.
Kertesz M, Safianowicz K, Bell T (2016) New insights into the microbial communities and biological activities that define mushroom compost. In Proceedings of the 19th International Society for Mushroom Science (ISMS) Conference, Baars,J.J.P., Sonnenberg, A.S.M., ISMS, 161-165.

Kües U, Khonsuntia W, Subba S, Dörnte B (2018) Volatiles in communication of Agaricomycetes. In Physiology and Genetics, T. Anke, and A. Schüfflerpp (eds). Cham, Switzerland: Springer.

Largeteau M L, Savoie J M. Microbially induced diseases of Agaricus bisporus: biochemical mechanisms and impact on commercial mushroom production. Appl Microbiol Biotechnol 2010;86:63-73

Largeteau M L, Savoie J M. Microbially induced diseases of Agaricus bisporus: biochemical mechanisms and impact on commercial mushroom production. Appl Microbiol Biotechnol 2010;86:63-7

McGee C F, Byrne H, Irvine A, Wilson J (2017) Diversity and dynamics of the DNA and cDNA-derived bacterial compost communities throughout the Agaricus bisporus mushroom cropping process. Ann Microbiol 67:751-761. https://doi.org/10.1007/s13213-0171303-1

Milijaševi c-Mar ci c S, Stepanovi c M, Todorovi c B, Duduk B, Stepanovi c J, Rekanovi c E, Poto cnik I (2017) Biological control of green mould on Agaricus bisporus by a native Bacillus subtilis strain from mushroom compost. Eur J Plant Pathol 148: 509519. DOI 10.1007/s 10658-016-1107-3

Mouthier T M B, Kilic B, Vervoort P, Gruppen H, Kabel M A (2017) Potential of a gypsum-free composting process of wheat straw for mushroom production. PLoS One 
12(10):e0185901.

https://doi.org/10.1371/journal.pone.01 85901

Natvig D O, Taylor J W, Tsang A, Hutchinson M I, Powell A J (2015) Mycothermus thermophilus gen. et comb. nov., a new home for the itinerant thermophile Scytalidium thermophilum (Torula thermophila). Mycologia 107(2):319327. https://doi.org/10.3852/13-399

Noble R, Gaze R H (1996) Preparation of mushroom (Agaricus bisporus) composts in controlled environments: factors influencing compost bulk density and productivity. Int Biodeterior Biodeg 37(1-2):93-100. https://doi.org/10.1016/09648305(95)00072-0

Pandin C, Védie R, Rousseau T, Le Coq D, Aymerich S, Briandet R (2018) Dynamics of compost microbiota during the cultivation of Agaricus bisporus in the presence of Bacillus velezensis QST713 as biocontrol agent against Trichoderma aggressivum. Biol Control 127: 39-54. https://doi.org/10.1016/j.biocontrol.20 18.08.022

Pratiksha K, Narute T K, Surabhi S, Ganesh A, Sujoy S (2017) Effect of liquid biofertilizers on the yield of button mushroom. J Mycopathol Res 55:135141.

Raj D R and Thangaraj A (2008) Post Harvest Technology Of Mushrooms Technical Bulletin. Publisher: Directorate of Mushroom Research, Solan, Himachal Pradesh-173213, India

Royse D J, Beelman R B (2016) Six steps to mushroom farming. Penn State Extension, Pennsylvania State University.

Schisler L C (1982) Biochemical and mycological aspects of mushroom composting. In: Penn State handbook for commercial mushroom growers, a compendium of scientific and technical information useful to mushroom farmers. Wuest PJ, Bengston GD, Eds. University Park, PA: The Pennsylvania State University, 3-10.

Seaby D A (1996) Investigation of the epidemiology of green mould of mushroom compost caused by Trichoderma harzianum. Plant Pathology 45:913-23. https://doi.org/10.1111/j.13653059.1996.tb02902.x

Sharma S, Kumar S (2000) Studies on wet bubble disease of white button mushrooms (Agaricus bisporus) caused by Mycogone perniciosa. Mushroom Sci. 15:569-575.

Sharma VP, Kumar S, Annepu S (2017) Technologies Developed by ICARDirectorate of Mushroom Research for Commercial Use. Technical Bulletin 11-13.

Siyoum N A, Surridge K, van der Linde E J, Korsten L (2016) Microbial succession in white button mushroom production systems from compost and casing to a marketable packed product. Ann Microbiol 66(1):151-164. https://doi.org/10.1007/s13213-0151091-4

Smith J F, Wood D A, Thurston C F (1995) Growth measurement of Agaricus mycelium in composted substrates as an indicator of compost selectivity and mushroom productivity. Mushroom Sci. 14: 293-301.

Stajić M, Vukojević J, Milovanović I, Ćilerdžić J, Knežević A (2016) Role of mushroom Mn-oxidizing peroxidases in biomass conversion. In: Gupta V. (eds) Microbial enzymes in bioconversion of biomass. Biofuel and Biorefinery Technologies. Springer, Cham. 3: 251-269. https://doi.org/10.1007/978-3-31943679-1_10 
Straatsma G, Olijnsma T W, Gerrits J P G, Amsing J G M, Op den Camp H J M, Van Griensven L J L D (1994) Inoculation of Scytalidium thermophilum in button mushroom compost and its effect on yield. Appl Environ Microbiol 60(9):3049-3054. http://aem.asm.org/

Vajna B, Szili D, Nagy A, Marialigeti K (2012) An improved sequence aided TRFLP analysis of bacterial succession during oyster mushroom substrate preparation. Microb Ecol 64(3):702713. https://doi.org/10.1007/s00248012-0063-5

Valdez-Vazquez I, A L Morales, A E Escalante (2017) History of adaptation determines short-term shifts in performance and community structure of hydrogen-producing microbial communities degrading wheat straw. Microb. Biotechnol 10(6):1569-1580. https://doi.org/10.1111/17517915.12678

Vieira F R, and Pecchia J A (2018) An exploration into the bacterial community under different pasteurization conditions during substrate preparation (composting phase II) for Agaricus bisporus cultivation. Microb Ecol 75: 318-330. https://doi.org/10.1007/s0024 8-0171026-7

Wang W D, Yan L, Cui Z J, Gao Y M, Wang Y J, Jing R Y (2011) Characterization of a microbial consortium capable of degrading lignocelluloses. Bioresour Technol 102(19):9321-9324. https://doi.org/10.1016/j.biortech.2011. 07.065

Wells J M, Sapers G M, Fett W F, Butterfield J E, Jones J B, Bouzar H, Miller F C (1996) Postharvest discoloration of the cultivated mushroom Agaricus bisporus caused by Pseudomonas tolaasii, $P$. reactans, and $P$. gingeri. Phytopathology 86(10):1098-1104. https://doi.org/10.1094/Phyto-86-1098

Zarenejad F, Yakhchali B, Rasooli I (2012) Evaluation of indigenous potent mushroom growth promoting bacteria (MGPB) on Agaricus bisporus production. World J Microbiol Biotechnol 28(1):99-104. https://doi.org/10.1007/s11274-0110796-1

Zhang C, Huang T, Shen C, Wang X, Qi Y, Shen J, et al., (2016) Down regulation of ethylene production increases mycelial growth and primordia formation in the button culinarymedicinal mushroom, Agaricus bisporus (Agaricomycetes). Int J Med Mushrooms18:1131-1140. https://doi.org/10.1615/IntJMedMushr ooms.v18.i12.80

Zhang X, Zhong Y H, Yang S D, Zhang W X, $\mathrm{Xu}$ M Q, Ma A Z, Zhuang G Q, Chen G J, Liu WF (2014) Diversity and dynamics of the microbial community on decomposing wheat straw during mushroom compost production. Bioresour Technol 170:183-195. https://doi. org/10.1016/j.biortech.2014.07.093

\section{How to cite this article:}

Kanika Mahajan, Sunil Kumar, Anil Rao and Ambrish Kumar Mahajan. 2021. Microbial Diversity and their Role in Agaricus bisporus Production. Int.J.Curr.Microbiol.App.Sci. 10(07): 405-413. doi: https://doi.org/10.20546/ijcmas.2021.1007.044 